\title{
Macro- and microelement concentrations of Finnish timothy in 1974 and 1987
}

\author{
RITVA MÄKELÄ-KURTTO, RAIMO ERVIÖ and JOUKO SIPPOLA
}

\begin{abstract}
MÄKELÄ-KuRtTo, R., ERVIÖ, R. \& SiPPOLA, J. 1993. Macro- and microelement concentrations of Finnish timothy in 1974 and 1987. Agric. Sci. Finl. 2: 337-344. (Agric, Res. Centre of Finland, Inst. of Soils and Environment, FIN-31600 Jokioinen, Finland.)

Macro- and microelement concentrations of timothy (Phleum pratense L.) in 1974 and 1987 were compared. Timothy samples were collected from the same Finnish fields in 1987 as in 1974 and analyzed for seventeen elements. The biogenic element concentrations of timothy were mostly unchanged or slightly decreased. The decreases were most probably due to differences in the weather conditions between the years and in the stage of development of the plants at the time of sampling. The decrease in timothy $\mathrm{Zn}$ was apparently caused by the decrease in soil $\mathrm{Zn}$. In 1987, the mineral nutritive value of timothy as animal feed was nearly the same as in 1974, but lower than the recommendations valid today.

In both years, the concentrations of harmful elements in timothy were low. A drastic decrease in $\mathrm{Pb}$ from 1974 to 1987 was due to a remarkable decrease in the $\mathrm{Pb}$ emissions from traffic into the atmosphere.

Timothy grown on fine mineral soils was rich in $\mathrm{K}, \mathrm{Al}, \mathrm{Cd}, \mathrm{Cu}$ and $\mathrm{Ni}$, while timothy from organic soils was rich in $\mathrm{P}, \mathrm{Mg}, \mathrm{Fe}$ and $\mathrm{Mo}$. The only clear regional difference was in the $\mathrm{Pb}$ concentration; it was higher in the south than up north.
\end{abstract}

Key words: grass, hay, minerals, heavy metals, soil type groups, cultivation zones

\section{Introduction}

Plants take up mineral elements mostly by their roots from the soil, but to some extent also by their leaves from the air. Changes in concentrations of both media may cause changes in concentrations of the plants. Soil characteristics are affected by cultivation practices like fertilization, liming, etc., and by atmospheric depositions. The quality of the air is influenced by emissions from natural and anthropogenic sources. Soil factors like texture, acidity and organic matter content influence the uptake of the elements. Weather conditions also regulate the uptake of different elements by the plants. Finally, the element concentrations of the plants are dependent on the plant species, cultivar and plant part in addition to the stage of development. However, elements occurring as structural components tend to vary less than those having specific metabolic functions in the plant.

In 1974, soil and timothy samples were collected from about 2000 sampling sites in different parts of Finland. The samples were analyzed for macro- and microelements. Research results of the soil survey were published by SIPPOLA and TARES (1978) and those of the timothy survey by KÄHÄRI and NISSINEN (1978) and by PAASIKALLIO (1978). In 1987, 1320 of the same fields were resampled; 1320 soil and 403 timothy samples were collected. The chemical characteristics of the soils were studied 


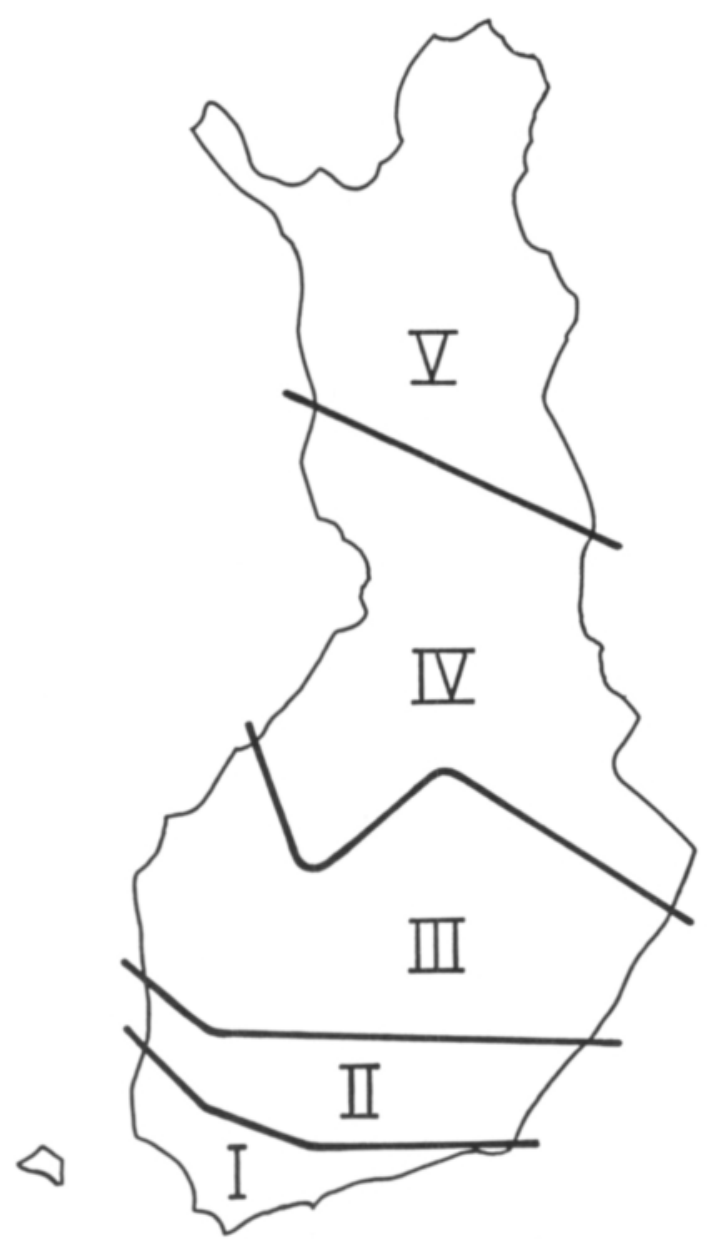

Fig. 1. Cultivation zones (I-V) in Finland.

within the Finnish Acidification Project, 19851989. The research results were published by ERVIÖ et al. (1990).

The aim of this study was to investigate the concentrations of macro- and microelements of the 1987 timothy samples and to compare them with those of 1974. The effects of soil characteristics, air quality and weather conditions were evaluated.

\section{Material and methods}

\section{Sampling}

In 1987, 407 timothy (Phleum pratense L.) samples were collected from five cultivation zones of Fin-
Table 1. Effective temperature and precipitation sums in 1974 and 1987 and long-term means in period of 1961-1990.

\begin{tabular}{|c|c|c|c|c|}
\hline $\begin{array}{l}\text { Meteorological } \\
\text { station }\end{array}$ & Date & 1974 & 1987 & $\begin{array}{c}\text { Mean } \\
1961-1990\end{array}$ \\
\hline & & \multicolumn{3}{|c|}{ Effective temperature sum $\left({ }^{\circ} \mathrm{C}\right)$} \\
\hline Helsinki & June 30 & 345 & 348 & 469 \\
\hline \multirow[t]{2}{*}{ latitude $60^{\circ}$} & July 10 & 443 & 450 & - \\
\hline & $-"-15$ & 494 & 496 & 634 \\
\hline Jyväskylä & June 30 & 324 & 319 & 408 \\
\hline \multirow{2}{*}{ latitude $62^{\circ}$} & July 10 & 427 & 415 & - \\
\hline & $-"-15$ & 481 & 445 & 562 \\
\hline Oulu & June 30 & 342 & 281 & 346 \\
\hline \multirow[t]{3}{*}{ latitude $65^{\circ}$} & July 10 & 453 & 373 & - \\
\hline & $-"-15$ & 513 & 404 & 505 \\
\hline & & \multicolumn{3}{|c|}{ Precipitation sum (mm) } \\
\hline Helsinki & $\begin{array}{l}\text { May 1- } \\
\text { July } 15\end{array}$ & 110 & 141 & $(132)^{1)}$ \\
\hline Jyväskylä & - " - & 129 & 175 & (174) \\
\hline Oulu & - " - & 126 & 154 & $(130)$ \\
\hline
\end{tabular}

1) May 1-July 31

land (Fig. 1); 403 were from the same fields as in 1974. Each plant sample (200-400 g DM) consisted of four subsamples which were taken from the four corners of the $10 \times 10 \mathrm{~m}$ sampling sites, which were at least $100 \mathrm{~m}$ away from the nearest highway and at least $50 \mathrm{~m}$ from the nearest electric line. Sampling was done after the spikes of timothy had formed but before flowering. Thus, in southern Finland timothy was sampled about two weeks earlier than in northern Finland.

The weather conditions during the two growing seasons are described in Table 1. It shows the effective temperature and precipitation sums in 1974 and 1987 and their means in 1961-1990 at three Finnish meteorological stations, i.e. Helsinki, Jyväskylä and Oulu. These stations were selected so as to cover nearly the whole sampling area.

\section{Plant analyses}

Before analyses timothy samples were air-dried at $60^{\circ} \mathrm{C}$ and ground in a hammer mill of pure carbon steel to pass a $2 \mathrm{~mm}$ sieve. Mineral element concentrations were expressed on a dry matter (DM) basis. 
DM contents of air-dry timothy samples were determined by drying them at $105^{\circ} \mathrm{C}$ for $4 \mathrm{~h}$. The samples were cooled in a desiccator for $2 \mathrm{~h}$ and weighed before ashing.

For determination of calcium $(\mathrm{Ca})$, potassium $(\mathrm{K})$, magnesium $(\mathrm{Mg})$, phosphorus $(\mathrm{P})$, aluminium (Al), cadmium (Cd), cobalt $(\mathrm{Co})$, chromium $(\mathrm{Cr})$, copper $(\mathrm{Cu})$, iron $(\mathrm{Fe})$, manganese $(\mathrm{Mn})$, molybdenum $(\mathrm{Mo})$, nickel $(\mathrm{Ni})$, lead $(\mathrm{Pb})$ and zinc $(\mathrm{Zn})$ concentrations, the timothy samples $(5.0 \mathrm{~g})$ were dry-ashed at $450^{\circ} \mathrm{C}$ overnight (Agricultural Research Centre 1986). The ash was moistened with a few drops of water and thereafter dissolved in $10 \mathrm{ml}$ of $3 \mathrm{~N} \mathrm{HCl}$ in a water bath. The hot solution was filtered into a $50 \mathrm{ml}$ volumetric flask by rinsing. The filter paper and residue were ashed again at $600^{\circ} \mathrm{C}$ and treated with $\mathrm{HF}$ to release the remaining elements in the residue.

The $\mathrm{Cd}, \mathrm{Co}, \mathrm{Mo}$ and $\mathrm{Pb}$ concentrations were measured by atomic absorption spectrophotometry (AAS) using a graphite furnace. The concentrations of other elements were determined by inductively coupled plasma atomic emission spectrometry (ICP-AES). For the determination of sulphur (S) and boron (B) concentrations, the timothy samples were wet-ashed in concentrated $\mathrm{HNO}_{3}$, and then measured by ICP-AES.

The methods of plant analyses employed for the timothy samples collected in 1974 have been described by KÄHÄRI and NISSINEN (1978) as well as by PAASIKALlio (1978). The element concentrations of timothy measured at the Agricultural Research Centre in 1974 and 1987 could be considered very comparable due to good and continuous quality control of analytical methods and quality assurance of analytical results.

\section{Statistical methods}

The statistical methods used were frequency analysis, t-test and analysis of variance. Statistical calculations were made separately for each cultivation zone (Fig. 1) and each soil type group which were: (A) coarse mineral soils (till, sand and finesand); (B) fine mineral soils (silt and clay); and (C) organic soils (peat, mould and gyttja).

\section{Results and discussion}

\section{Changes from 1974 to 1987}

\section{Macroelements}

The mean concentrations of $\mathrm{Ca}, \mathrm{K}, \mathrm{Mg}$ and $\mathrm{P}$ of timothy were lower in 1987 than in 1974 even though the extractable concentrations of the soil elements did not change or they even increased (ERviö et al. 1990). The mean decreases varied between $10-17 \%$ (Table 2).

The decreases in $\mathrm{Ca}$ and $\mathrm{Mg}$ concentrations during the study period most probably resulted from the differences in the weather conditions between the growing seasons and in the stage of development of timothy. In 1987, the effective temperature sums were lower and precipitation sums higher than in 1974 (Table 1), and the plant samples were collected at a slightly earlier and less mature stage of development. According to KERÄNEN (1941), the Ca concentrations in timothy are usually lower in younger plants and increase up to flowering. Similarly, the $\mathrm{Mg}$ concentration of the plants generally increases with age (DAVIES and LANE 1982). SVANBERG and EKMAN (1946) showed that the Mg concentration of timothy does not increase during two weeks at the time of flowering.

The timothy $\mathrm{P}$ and $\mathrm{K}$ concentrations decreased by $10 \%$ from 1974 to 1987 . These are elements, which usually decrease with age of the plants (KERÄNEN 1941, SALO et al. 1990).

The mean S concentration of timothy in 1987 was about the same as that reported by SILLANPÄÄ and JANSSON (1991), whereas, the mean S concentration of timothy grown on acid sulphate soils (PALKO 1986) was clearly lower than that reported in the present study.

\section{Microelements}

The mean boron concentration of timothy did not change from 1974 to 1987 (Table 2), although B was added each year into the soils as a component of all NPK fertilizers since 1972 and soluble B in the soils significantly increased between 1974 and 1987 (ERVIÖ et al. 1990). Younger plants usually 
Table 2. Means and ranges of mineral element concentrations of timothy samples $(n=403)$ in 1987 and mean differences from 1974. Concentrations expressed on a dry matter (DM) basis.

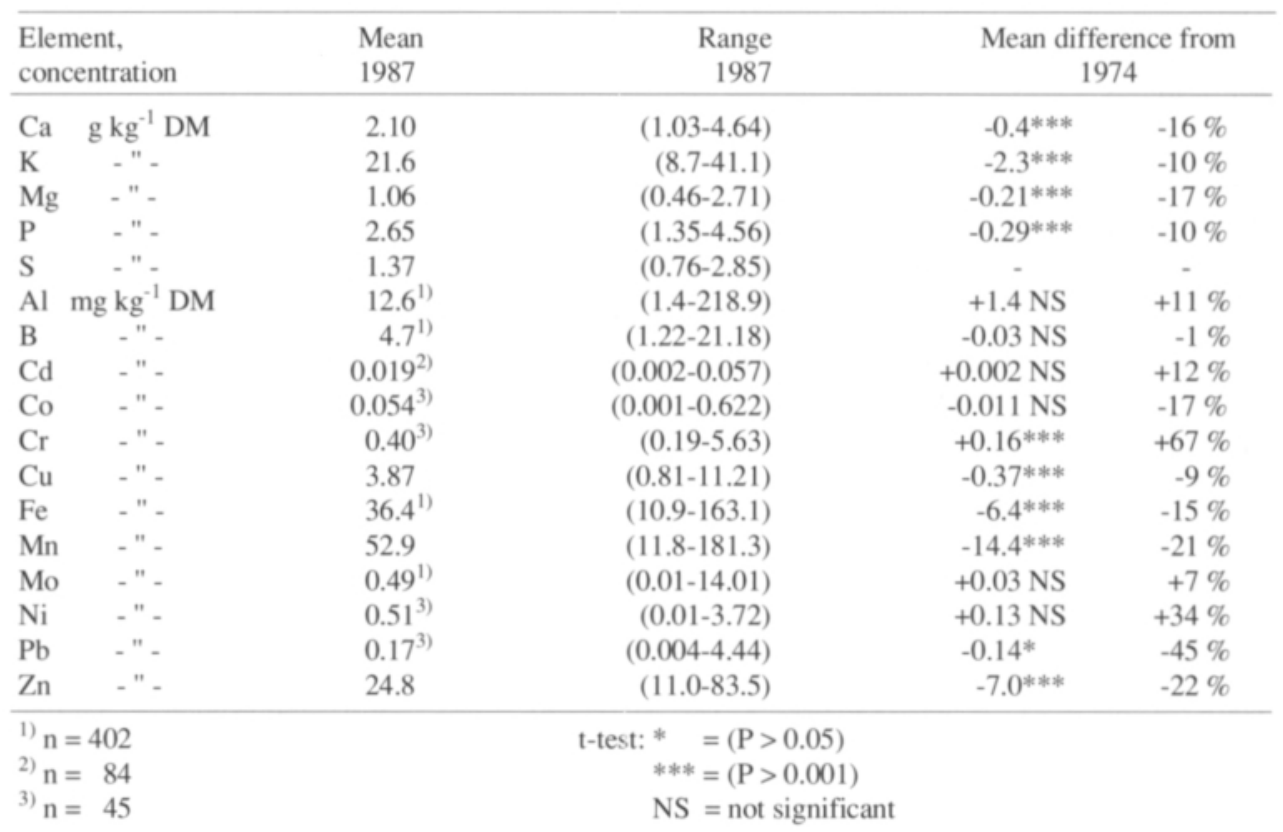

contain lower concentrations of B (SMITH 1962). Most probably that is the reason for plant B not being changed.

Similarly, less mature plants have lower Fe and Mn concentrations (SMITH 1962). Due to age, timothy $\mathrm{Fe}$ and $\mathrm{Mn}$ decreased in spite of the increase in soil Fe and no change in soil Mn from 1974 to 1987 (ERVIÖ et al. 1990). The mean concentrations of Co and Mo were about the same in 1987 and 1974, although the concentrations of these elements increased in soils (ERVIÖ et al. 1990).

From 1974 to 1987 , the mean $\mathrm{Cu}, \mathrm{Mn}$ and $\mathrm{Zn}$ concentrations of timothy decreased by 9,21 and $22 \%$, respectively. During the study period, soil extractable $\mathrm{Cu}$ increased by $32 \%$, Mn did not change, and $\mathrm{Zn}$ decreased by $22 \%$. The decrease in soil $\mathrm{Zn}$ apparently decreased the concentration of $\mathrm{Zn}$ in timothy, too. Moreover, the higher $\mathrm{pH}$-value of the soils in 1987 (ERVIÖ et al. 1990) may have reduced the availability of these micronutrients to plants.

\section{Harmful elements}

Between 1974 and 1987, there were no changes in the mean $\mathrm{Al}$ and $\mathrm{Ni}$ concentrations of timothy samples (Table 2) or soil samples (ERVIÖ et al. 1990). Particularly high Al concentrations in timothy were reported by PALKO (1986) on Finnish acid sulphate soils which were few in this study.

The mean Cd concentration of timothy in 1987 did not differ significantly from that in 1974 , even though the concentrations of soluble $\mathrm{Cd}$ in soils increased by $30 \%$ (ERVIÖ et al. 1990). On the other hand, $\mathrm{Cd}$ depositions have gradually decreased in northern Europe during the last decades (Nordic Council of Ministers 1992). The major part of plant Cd originates usually from the soil, but $20-60 \%$ of herbage $\mathrm{Cd}$ can be directly deposited from the air (Hovmand et al. 1983). Atmospheric Cd may be absorbed into the plant and transported throughout it. Furthermore, soil $\mathrm{pH}$ that strongly regulates the uptake of Cd by the plants (ANDERSSON and 
NILSSON 1974), was higher in 1987 than in 1974 (ERVIÖ et al. 1990).

The mean increase in the timothy $\mathrm{Cr}$ from 1974 to 1987 was $67 \%$, whereas extractable soil $\mathrm{Cr}$ increased by $17 \%$. In general, most of the plant $\mathrm{Cr}$ originates from the air (MOSBAEK and TJELL 1985).

A drastic decrease in the mean $\mathrm{Pb}$ concentrations of timothy was between the two years. In 1987, the concentration was $45 \%$ lower than in 1974 . The decrease was due to the remarkable decline in domestic emissions of $\mathrm{Pb}$ into the air from traffic between 1974 and 1987. In the 1970's, the total emissions of $\mathrm{Pb}$ from automobiles in Finland were about 1000 tons per year (Finnish Ministry of Internal Affairs 1981). The $\mathrm{Pb}$ concentration of petrol was gradually reduced in the 1980 's and $\mathrm{Pb}$-free fuel has been available since 1985 (Finnish Ministry of Environment 1989).

In 1987, $\mathrm{Pb}$ emissions from traffic in Finland amounted to 200-300 tons. Still, automobile traffic was the principal source of $\mathrm{Pb}$ emissions into the air (VoRnAmo 1984). Depositions are usually responsible for more than $90 \%$ of plant $\mathrm{Pb}$ (MOSBAEK at al. 1989). Thus, a notable decrease in the $\mathrm{Pb}$ emissions must have influenced the $\mathrm{Pb}$ concentrations of timothy. A positive effect of diminished $\mathrm{Pb}$ emissions on the $\mathrm{Pb}$ concentration of the plants was observed also by MÄKELÄ-KURTTO and TARES (1987); the mean $\mathrm{Pb}$ concentration of one-year old pine needles in the Helsinki area decreased to one third from 1970 to 1986.

\section{Differences between soil type groups}

Timothy plants grown on coarse mineral soils contained less elements than the plants grown on other soil types, on average (Table 3 ). $\mathrm{Zn}$ was an exception; the highest concentration was observed in timothy grown on coarse mineral soils.

The lowest mean $\mathrm{Ca}$ and $\mathrm{B}$ concentrations and the highest $\mathrm{K}, \mathrm{Cd}$ and $\mathrm{Cu}$ concentrations were in the samples collected from fine mineral soils. Similarly, according to SIPPOLA and MÄKELÄ-KURTTO (1986), the mean Cd concentration of timothy grown on clay soil was higher than that of timothy grown on organic or coarse mineral soils. $\mathrm{Al}$ and $\mathrm{Ni}$ concentrations of timothy from fine mineral soils
Table 3. Means of macro- and microelement concentrations of timothy by soil type group ( $\mathrm{A}=$ coarse mineral soils; $\mathrm{B}=$ fine mineral soils; $\mathrm{C}=$ organic soils) in 1987. Concentrations expressed on a dry matter (DM) basis.

\begin{tabular}{|c|c|c|c|c|}
\hline \multirow{3}{*}{\multicolumn{2}{|c|}{$\begin{array}{l}\text { Year } \\
\text { Soil type group } \\
\text { No of samples }\end{array}$}} & \multicolumn{3}{|c|}{1987} \\
\hline & & \multirow{3}{*}{$\begin{array}{c}\mathrm{A} \\
232 \\
2.15^{\mathrm{b}}\end{array}$} & \multirow{3}{*}{$\begin{array}{c}\mathrm{B} \\
75 \\
1.90^{\mathrm{a}}\end{array}$} & \multirow{3}{*}{$\begin{array}{c}\mathrm{C} \\
100 \\
2.13^{t}\end{array}$} \\
\hline & & & & \\
\hline $\mathrm{Ca}$ & $\mathrm{g} \mathrm{kg}^{-1} \mathrm{DM}$ & & & \\
\hline K & - " - & $21.8^{b}$ & $23.7^{c}$ & $19.7^{a}$ \\
\hline $\mathrm{Mg}$ & - " - & $1.02^{\mathrm{a}}$ & $1.03^{\mathrm{a}}$ & $1.17^{\mathrm{t}}$ \\
\hline $\mathrm{P}$ & - " - & $2.58^{\mathrm{a}}$ & $2.62^{a}$ & $2.84^{\mathrm{b}}$ \\
\hline $\mathrm{S}$ & $-"-$ & 1.36 & 1.34 & 1.40 \\
\hline $\mathrm{Al}$ & $\mathrm{mg} \mathrm{kg}^{-1} \mathrm{DM}$ & $11.0^{\mathrm{a}}$ & $20.2^{\mathrm{b}}$ & $10.8^{\mathrm{a}}$ \\
\hline B & - " - & $4.83^{b}$ & $4.01^{\mathrm{a}}$ & $5.08^{\mathrm{b}}$ \\
\hline $\mathrm{Cd}$ & - " - & $0.020^{\mathrm{ab}}$ & $0.021^{b}$ & $0.017^{\mathrm{a}}$ \\
\hline Co & - " - & 0.042 & 0.062 & 0.057 \\
\hline $\mathrm{Cr}$ & - " - & 0.42 & 0.50 & 0.41 \\
\hline $\mathrm{Cu}$ & - " - & $3.76^{\mathrm{a}}$ & $4.46^{\mathrm{b}}$ & $3.69^{\mathrm{a}}$ \\
\hline $\mathrm{Fe}$ & - " - & $34.0^{\mathrm{a}}$ & $39.2^{\mathrm{ab}}$ & $40.3^{\mathrm{t}}$ \\
\hline Mn & - " - & 51.0 & 57.8 & 54.3 \\
\hline Mo & - " - & $0.40^{\mathrm{a}}$ & $0.35^{\mathrm{a}}$ & $0.82^{\mathrm{b}}$ \\
\hline $\mathrm{Ni}$ & - " - & $0.36^{\mathrm{a}}$ & $0.80^{b}$ & $0.40^{2}$ \\
\hline $\mathrm{Pb}$ & - " - & 0.12 & 0.16 & 0.19 \\
\hline $\mathrm{Zn}$ & - " - & $26.3^{b}$ & $22.2^{\mathrm{a}}$ & $23.5^{\mathrm{a}}$ \\
\hline
\end{tabular}

Means in each row followed by a common index letter do not differ at $\mathrm{P}=0.05$ within the year.

were nearly twice as high as the respective values in timothy from other soils.

The plants grown on organic soils had the highest mean $\mathrm{P}, \mathrm{Mg}, \mathrm{Fe}$ and Mo values and the lowest mean $\mathrm{Cd}$ value. The Mo concentration of timothy grown on organic soil was about two times that grown on other soils. This is in accordance with an observation of PAASIKALLIO (1978). As to differences between the years by soil type group, the decreases in the concentrations of macroelements in timothy from 1974 (КӒHÄRI and NISSINEN 1978) to 1987 were the most notable on organic soils.

\section{Differences by cultivation zone}

Clear differences in the mineral element concentrations of timothy between the cultivation zones were very few (Table 4). The Pb concentrations of timothy, like those of cultivated soils (ERVIÖ et al. 1990), clearly diminished from the south to the 
Table 4. Means of macro- and microelement concentrations of timothy by plant cultivation zone in 1987. Concentrations expressed on a dry matter (DM) basis.

\begin{tabular}{|c|c|c|c|c|c|c|}
\hline \multirow{3}{*}{\multicolumn{2}{|c|}{$\begin{array}{l}\text { Year } \\
\text { Cultivation zone } \\
\text { No of samples }\end{array}$}} & \multicolumn{5}{|c|}{1987} \\
\hline & & \multirow{3}{*}{$\begin{array}{r}\text { I } \\
6 \\
2.06\end{array}$} & \multirow{3}{*}{$\begin{array}{r}\text { II } \\
74 \\
2.06\end{array}$} & \multirow{3}{*}{$\begin{array}{c}\text { III } \\
195 \\
2.13\end{array}$} & \multirow{3}{*}{$\begin{array}{r}\text { IV } \\
97 \\
2.01\end{array}$} & \multirow{3}{*}{$\begin{array}{r}\mathrm{V} \\
35 \\
2.24\end{array}$} \\
\hline & & & & & & \\
\hline & $\mathrm{g} \mathrm{kg}^{-1} \mathrm{DM}$ & & & & & \\
\hline K & -" - & 23.0 & 22.2 & 21.2 & 21.0 & 24.6 \\
\hline $\mathrm{Mg}$ & - " - & 1.11 & 0.96 & 1.02 & 1.18 & 1.18 \\
\hline$P^{\circ}$ & - " - & $2.62^{\mathrm{a}}$ & $2.60^{\mathrm{a}}$ & $2.60^{\mathrm{a}}$ & $2.64^{\mathrm{a}}$ & $3.10^{b}$ \\
\hline $\mathrm{S}$ & - " - & 1.56 & 1.34 & 1.36 & 1.36 & 1.39 \\
\hline & $\mathrm{mg} \mathrm{kg}^{-1} \mathrm{DM}$ & 19.2 & 17.9 & 12.0 & 11.5 & 7.8 \\
\hline B & - - - & $4.53^{\mathrm{a}}$ & $3.77^{\mathrm{a}}$ & $4.44^{\mathrm{a}}$ & $5.23^{\mathrm{a}}$ & $7.18^{\mathrm{b}}$ \\
\hline $\mathrm{Cd}$ & - " - & 0.022 & 0.020 & 0.019 & 0.018 & 0.023 \\
\hline Co & - " - & 0.034 & 0.051 & 0.042 & 0.066 & 0.048 \\
\hline $\mathrm{Cr}$ & -" - & 0.41 & 0.46 & 0.42 & 0.44 & 0.44 \\
\hline $\mathrm{Cu}$ & - " - & 4.82 & 4.01 & 3.76 & 3.83 & 4.11 \\
\hline $\mathrm{Fe}$ & - " - & 42.7 & 37.1 & 35.3 & 37.5 & 38.6 \\
\hline Mn & - " - & 59.3 & 58.5 & 50.8 & 50.8 & 59.5 \\
\hline Mo & -" - & 0.26 & 0.69 & 0.53 & 0.36 & 0.24 \\
\hline $\mathrm{Ni}$ & -" - & 0.71 & 0.63 & 0.45 & 0.40 & 0.56 \\
\hline $\mathrm{Pb}$ & - " - & $0.29^{b}$ & $0.24^{a b}$ & $0.12^{\mathrm{ab}}$ & $0.14^{\mathrm{ab}}$ & $0.06^{\mathrm{a}}$ \\
\hline $\mathrm{Zn}$ & - " - & $25.8^{\mathrm{a}}$ & $24.7^{\mathrm{a}}$ & $23.8^{\mathrm{a}}$ & $24.3^{\mathrm{a}}$ & $32.4^{\mathrm{b}}$ \\
\hline
\end{tabular}

Means in each row followed by a common index letter do not differ at $\mathrm{P}=0.05$ within the year.

north, because traffic density and $\mathrm{Pb}$ emissions diminished to the same direction, too. Furthermore, the decrease in the timothy $\mathrm{Pb}$ from 1974 to 1987 was the most significant in southern Finland (ERVIÖ 1989) due to the most remarkable decrease in the $\mathrm{Pb}$ emissions there.

The mean $\mathrm{P}, \mathrm{B}$ and $\mathrm{Zn}$ concentrations were the highest in timothy from the northernmost cultivation zone (V). This might be due to the differences in the soil types. In this study, dominating soil types in southern Finland were fine mineral soils and in northern Finland coarse mineral soils. In addition to this, the proportion of organic soils was greater in the north than in the south (ERVIÖ et al. 1990).

\section{Nutritive value of timothy}

The nutritive value of timothy is of importance, since timothy is one of the main forage plants cultivated for animal feeds in Finland. Optimal element concentrations of the grass for cattle feeding are: $\mathrm{Ca}$ $4.0-4.5$ g, K 20-30 g, Mg 2 g, Fe 100 mg, Cu 10 mg,
Mn $40 \mathrm{mg}$, Mo $0.3 \mathrm{mg}$ and Co $0.1 \mathrm{mg} \mathrm{kg}^{-1} \mathrm{DM}$ (SALO et al. 1990, Association of Rural Advisory Centres 1992). The optimal range of K concentrations is rather narrow in grass, because concentrations lower than $20 \mathrm{~g} \mathrm{~kg}^{-1} \mathrm{DM}$ indicate $\mathrm{K}$ deficiency in the plants and those higher than $30 \mathrm{~g} \mathrm{~kg}^{-1}$ DM are excessive for animals (Kasvata nurmiviljelyn tulosta ... 1993). Considering the stage of development of the plants, the mineral element concentrations of timothy obtained here were about the same as those reported by LAKANEN (1969) and by KÄHÄRI and NISSINEN (1978), but lower than the values recommended today.

\section{Conclusions}

The differences in the mineral element concentrations of timothy between 1974 and 1987 were mainly due to the weather conditions and the stage of development of the plants. However, some supportive measures, e.g. $\mathrm{Zn}$ fertilization, may be 
needed to optimize the nutritive value of grass for animal feeding. The purity of grass can be en- hanced by reducing emissions of heavy metals into the atmosphere.

\section{References}

Agricultural Research Centre 1986. Methods of soil and plant analysis. 45 p. Agric. Res. Centre of Finland, Dept. of Soil Science, Jokioinen, Finland.

ANDERsson, A. \& Nilsson, K. 1974. Influence of lime and soil $\mathrm{pH}$ on Cd availability to plants. Ambio 3: 198-200.

Association of Rural Advisory Centres 1992. Nautakarjan rehut. Tieto tuottamaan $63.118 \mathrm{p}$.

DAvies, G.R. \& LANE, P.W. 1982. Magnesium uptake into grass - results of a long term experiment. Expl. Husb. 38: 87-98.

ERvıö, R. 1989. Lyijypitoisuuden muutos viljelymaissa. Koetoim. ja Käyt. 46: 66.

—, MÄKel.̈̈-Kurtto, R. \& SipPola, J. 1990. Chemical characteristics of Finnish agricultural soils in 1974 and in 1987. In: Kauppi, P. et al. (eds.). Acidification in Finland. Springer-Verlag, Berlin. p. 214-234.

Finnish Ministry of the Environment 1989. Air conservation in Finland. 31 p. Finnish Ministry of the Environment, Environmental Protection Department, Helsinki. Brochure 14.

Finnish Ministry of Internal Affairs 1981. A report on air pollution with regard to road traffic. 99 p. Series A:7. Finnish Ministry of Internal Affairs, Department of Environment Conservation, Helsinki.

Hovmand, M.F., Tuel., J.C. \& Mosbaek, H. 1983. Plant uptake of airborn cadmium. Environmental Pollution Series A, 30: 27-38.

KÄHÄRI, J. \& Nissinen, H. 1978. The mineral element contents of timothy (Phleum pratense L.) in Finland. I. The elements calcium, magnesium, phosphorus, potassium, chromium, cobalt, copper, iron, manganese, sodium and zinc. Acta Agric. Scand. Suppl. 20: 26-39.

Kasvata nurmiviljelyn tulosta - satotaso ratkaisee. 1993. Leipä leveämmäksi -liite 1: 4-7.

KERÄNEN, T. 1941. Korjuuajan vaikutuksesta heinän kivennäisaineiden määrään. Referat: Über den Einfluss der Erntezeit auf die Mineralstoffmenge des Heus. Maatal.tiet. Aikak. 13: 23-27.

LAKANEN, E. 1969. Mineral composition of Finnish timothy. Ann. Agric. Fenn. 8: 20-29.

MÄKEL_Ä-KURTTO, R. \& TARES, T. 1987. Männyn neulasten lyijypitoisuudet Helsingin seudulla 1970 ja 1986. Abstract: Lead content of pine needles around Helsinki 1970 and 1986. Aquilo Ser. Bot. 25: 75-81.

Mosbaek, H. \& TJell, J.C. 1985. Report on the activities of the subnetwork on the passage of airborne trace elements to agricultural soils and crops. FAO Report of the 1985 consultation of the European cooperative network on trace elements. Appendix 5: 1-5.

—, Tuel., J.C. \& Hovmand, M.F. 1989. Atmospheric lead input to agricultural crops in Denmark. Chemosphere 19: 1787-1799.

Nordic Council of Ministers 1992. Atmospheric Heavy Metal Deposition in Northern Europe 1990. 41 p. Nord 12.

PaAsikallio, A. 1978. The mineral element contents of timothy (Phleum pratense L.) in Finland. II. The elements aluminium, boron, molybdenum, strontium, lead and nickel. Acta Agric. Scand. Suppl. 20: 40-52.

PALKo, J. 1986. Mineral element content of timothy (Phleum pratense L.) in an acid sulphate soil area of Tupos village, Northern Finland. Acta Agric. Scand. 36: 399-409.

SAlo, M.-L., Tuori, M. \& KiISKInEN, T. 1990. Ruokintataulukot ja ruokintanormit. [Feed tables and feeding norms, in Finnish]. 70 p. Helsinki.

SillanpäÄ, M. \& Jansson, H. 1991. Cadmium and sulphur contents of different plant species grown side by side. Ann. Agric. Fenn. 30: 407-413.

SipPola, J. \& MÄKElÄ-Kurtto, R. 1986. Cadmium in cultivated Finnish soils. Ann. Agric. Fenn. 25: 255-263.

— \& TARES, T. 1978. The soluble content of mineral elements in cultivated Finnish soils. Acta Agric. Scand. Suppl. 20: 11-25.

SмrTH, P.F. 1962. Mineral analysis of plant tissues. Ann. Rev. Plant Physiol. 13: 81-108.

SvanberG, O. \& Ekman, P. 1946. Om magnesiumhalten i vegetationen från svenska jordar. Summary: On the content of magnesium in vegetation from Swedish soils. Kungl. Lantbr. Akad. Tidskr. 85: 54-99.

VORNAMO, H. 1984. Liikenteen päästöjen kehityksestä. [Estimates for the emissions from traffic, in Finnish]. Ympäristö ja Terveys 15: 114-122.

\section{Manuscript received January 1993}

Ritva Mäkelä-Kurtto

Raimo Erviö

Jouko Sippola

Agricultural Research Centre of Finland

Institute of Soils and Environment

FIN-31600 Jokioinen, Finland 


\title{
SELOSTUS
}

\section{Suomalaisen timotein alkuainepitoisuudet vuosina 1974 ja 1987}

\author{
RITVA MÄKELÄ-KURTTO, RAIMO ERVIÖ ja JOUKO SIPPOLA
}

\author{
Maatalouden tutkimuskeskus
}

Koko Suomen alueelta vuonna 1987 tähkimisvaiheessa kerätyistä timoteinäytteistä analysoitiin 17 alkuainetta, joiden pitoisuuksia verrattiin 13 vuotta aikaisemmin samoilta paikoilta kerättyjen näytteiden vastaaviin pitoisuuksiin. Myös maalajien ja viljelyvyöhykkeiden merkitystä timotein alkuainekoostumukseen tarkasteltiin.

Timoteinäytteiden keskimääräiset kalsium-, kalium-, magnesium-, fosfori-, kupari-, mangaani-, rauta-, lyijy- ja sinkkipitoisuudet olivat vuonna 1987 pienempiä kuin vuonna 1974 Alumiinin, boorin, kadmiumin, koboltin, molybdeenin ja nikkelin arvot eivät poikenneet kyseisinä vuosina. Timotein kromipitoisuus oli vuonna 1987 suurempi kuin vuonna 1974.
Todetut erot timotein alkuainepitoisuuksissa johtunevat pääasiassa eroista kasvukausien sääoloissa ja timotein kehitysasteessa. Timotein sinkkipitoisuuden pienenemisen syy oli viljelymaiden helppoliukoisen sinkin väheneminen. Kasvien lyijypitoisuuden pieneneminen oli seurausta liikenteen lyijypäästöjen oleellisesta vähenemisestä tutkimusaikavälillä.

Eloperäisiltä mailta kerätyt timoteinäytteet sisälsivăt enemmän magnesiumia, fosforia, molybdeenia ja rautaa, mutta vähemmän kadmiumia kuin kivennäismailta kerätyt näytteet. Pohjoisimmalla viljelyvyöhykkeellä kasvaneesta timoteista todettiin alhaisimmat lyijypitoisuudet. 